\title{
Kreativitas Guru dalam Menggunakan Media Pembelajaran di SD Negeri 075082 Marafala* $^{*}$
}

\author{
Teacher's Creativity in Using Instructional Media at State Elementary School \\ 075082 Marafala
}

\author{
Noni Asriyana Telaumbanua ${ }^{1 凶} \mid$ Delipiter Lase $^{2} \mid$ Amurisi Ndraha ${ }^{3}$ \\ ${ }^{1}$ Program Studi S1 Pendidikan Agama Kristen STT Banua Niha Keriso Protestan Sundermann \\ ${ }^{23}$ STT Banua Niha Keriso Protestan Sundermann \\ nonyte1123@gmail.com
}

Received: 24 September 2021 | Revised: 27 October 2020 | Accepted: 28 October 2021 | Published online: 29 October 2021 Copyright (C) The Author(s) 2021

\begin{abstract}
This study aims to explain the teachers' creativity in using instructional [learning] media, knowing the factors causing the low creativity of teachers, and describing efforts to increase teacher creativity in developing and using instructional media. This study uses a qualitative method; the teachers and principal of State Elementary School 075082 Marafala were selected as the data source, and analyzed with the interactive model by Miles \& Huberman. The results showed that the creativity of teachers in developing and using instructional media was still relatively low. It is caused by the limited means and facilities to support learning and obstacles in the teacher himself. Based on the study's findings, the authors recommend that schools develop learning facilities, including teaching media, pay attention to improving the competence of teachers through training. Teachers need to enhance their competencies independently, colaboration with peers, and even involve students in designing and developing instructional media.
\end{abstract}

Keywords: Christian religious education, CRE teachers, instructional media, teacher's creativity

\begin{abstract}
Abstrak
Penelitian ini bertujuan untuk menjelaskan kreativitas guru dalam menggunakan media pembelajaran, mengetahui faktor-faktor penyebab rendahnya kreativitas guru, serta menjelaskan upaya meningkatkan kreativitas guru dalam mengembangkan dan menggunakan media pembelajaran. Penelitian ini menggunakan metode kualitatif, para guru dan kepada sekolah SD Negeri 075082 Marafala dipilih sebagai sumber data. Data yang terkumpul dianalisis dengan interactive model Miles \& Huberman. Hasil penelitian menunjukkan bahwa kreativitas guru dalam mengembangkan dan menggunakan media pembelajaran masih tergolong rendah. Ini disebabkan oleh terbatasnya sarana dan fasilitas pendukung pelaksanaan pembelajaran, serta hambatan dalam diri guru itu sendiri. Berdasarkan temuan penelitian itu, penulis merekomendasi agar sekolah mengembangkan fasilitas pembelajaran termasuk di dalamnya media pengajaran, memberi perhatian terhadap peningkatan kompetensi para guru melalui pelatihan, serta guru perlu meningkatkan kompetensinya secara mandiri, bekerja sama dengan rekan sejawat dan bahkan melibatkan peserta didik dalam merancang dan mengembangkan media pembelajaran.
\end{abstract}

Kata kunci: guru PAK, kreativitas guru, media pembelajaran, pendidikan agama Kristen

\section{Pendahuluan}

Guru merupakan salah satu komponen penting dalam kegiatan belajar mengajar yang berperan dalam usaha pembentukan sumber daya manusia yang potensial di bidang pembangunan. Dalam upaya meningkatkan mutu pendidikan dewasa ini, guru harus memiliki kreativitas dalam proses pembelajaran dan juga sangat diharapkan agar setiap guru yang mengajar adalah seorang guru 
yang profesional. ${ }^{1}$ Peranan kreativitas guru tidak sekedar membantu proses pembelajaran satu aspek dalam diri manusia saja, namun mencakup aspek lain yakni kognitif, afektif dan psikomotorik. Kreativitas guru sangat membantu menyelesaikan pekerjaannya secara dengan efisien. ${ }^{2}$

Secara umum, kreativitas dapat diartikan sebagai pola pemikiran atau gagasan yang muncul secara spontan dan imajinatif, yang mencirikan pencapaian artistik, penemuan ilmiah, dan kreasi mekanis. Dalam KBBI, kreativitas adalah kemampuan untuk mencipta, perihal berkreasi, dan kekreatifan. ${ }^{3}$ Dengan demikian, Kreativitas adalah kemampuan seseorang untuk menciptakan atau menghasilkan sesuatu yang baru atau orisinal, yang sebelumnya tidak diketahui, atau untuk memecahkan masalah baru yang dihadapi. Dalam kaitan proses belajar-mengajar, guru yang kreatif adalah "seseorang yang memilki kemampuan untuk menciptakan hal-hal baru dalam mengajar sehingga memiliki variasi di dalam mengajar yang akan membuat anak didik aktif dan kreatif."

Proses pembelajaran dikatakan kreatif manakala guru mampu berkreasi, berimajinasi, berinovasi, dan melakukan hal-hal artistik lainnya. Dicirikan dengan adanya "keaslian dan hal yang baru, baik berupa gagasan maupun karya nyata yang relatif berbeda dengan yang sebelumnya."

Kreativitas guru dalam pembelajaran sangat berpengaruh terhadap pemahaman anak, karena semakin kreatif guru dalam menyajikan materi maka semakin mudah anak memahaminya; dan membuat anak semakin kreatif dalam pembelajaran. Jika guru lebih kreatif dalam pembelajaran, anak tidak akan bosan mengikuti pelajaran. Guru juga akan lebih mudah untuk menciptakan lingkungan

*Artikel ini merupakan intisari Skripsi Noni Asriyana Telaumbanua, "Upaya Meningkatkan Kreativitas Guru dalam Menggunakan Media Pembelajaran di Sekolah Dasar Negeri 075082 Marafala" (STT BNKP Sundermann, 2021).

${ }^{1}$ Tholib Kasan, Dasar-Dasar Pendidikan (Jakarta: Studia Press, 2009), 12.

2 A. M. Sardiman, Interaksi Dan Motivasi Belajar Mengajar (Jakarta: PT Raja Grafindo Persada, 2016), 125.

${ }^{3}$ Departemen Pendidikan Nasional, Kamus Besar Bahasa Indonesia, 4th ed. (Jakarta: PT Gramedia Pustaka Utama, 2008), 739.

${ }^{4}$ Yanti Oktavia, "Usaha Kepala Sekolah Dalam Meningkatkan Kreativitas Guru Dalam Pembelajaran Di Sekolah Dasar," Jurnal Bahana Manajemen Pendidikan 2, no. 1 (2014): 808-831,

http://ejournal.unp.ac.id/index.php/bahana/article/view/3828.

${ }^{5}$ Beni S. Ambarjaya and Elin Marlina, Model-Model

Pembelajaran Kreatif, 1st ed. (Bogor: Regina Publishing and Printing, 2008), 54. kelas yang kondusif. Itulah peran penting yang dimainkan guru bagi siswanya.

Beberapa hasil penelitian sebelumnya memberi bukti bahwa kreativitas guru memiliki korelasi positif terhadap pencapaian akademik peserta didik. Di antaranya hasil penelitian Tri Ani Oktaria, dkk (2017) menunjukkan bahwa ada pengaruh kreativitas mengajar guru terhadap hasil belajar siswa. ${ }^{6}$ "Guru atau pendidik yang mempunyai tingkat kreativitas tinggi dalam mengajar akan menghasilkan siswa yang mempunyai prestasi belajar lebih baik dan sebaliknya."7

Belajar mengajar merupakan aktivitas guru dan siswa untuk mencapai tujuan tertentu. Definisi lain dari adalah "usaha guru menciptakan kondisikondisi atau mengatur lingkungan sedemikan rupa, sehingga terjadi interaksi antara peserta didik dengan lingkungan, termasuk guru, alat pengajaran, dan sebagainya yang disebut proses belajar, sehingga tercapai tujuan pembelajaran yang telah ditentukan." ${ }^{8}$ Demikian halnya dalam pengajaran guru, pendidik diharapkan dapat menggunakan media sebagai alat bantu pembelajaran. Dengan media, pembelajaran akan lebih efektif; siswa lebih mudah menerima materi yang disajikan guru, terlibat aktif serta pengajaran pun akan lebih menarik dan menyenangkan. ${ }^{9}$

Media pembelajaran adalah sarana untuk meningkatkan kegiatan proses belajar mengajar serta alat bantu guru untuk menyampaikan materi ajar, meningkatkan kreativitas dan perhatian siswa dalam proses pembelajaran. Dengan menggunakan media, siswa akan lebih termotivasi untuk belajar, imajinasi siswa terstimulasi, emosi tersentuh dan kesan yang mendalam diperoleh peserta didik.

Dalam dunia pendidikan, media berfungsi sebagai sarana untuk mencapai tujuan

${ }^{6}$ Tri Ani Oktaria and Riswan Jaenudin, "Pengaruh Kreativitas Mengajar Guru Terhadap Hasil Belajar Siswa Pada Mata Pelajaran Ekonomi Di SMA N 1 Muara Padang Banyuasin Sumatera Selatan," PROFIT 4, no. 2 (2017): 145154, https://ejournal.unsri.ac.id/index.php/jp/article/view/5593.

${ }^{7}$ Tinton Tri Pebrianto and M Tauchid Noor, "Pengaruh Kreativitas Guru Mengajar Dan Minat Belajar Siswa Terhadap Hasil Prestasi Siswa Kelas XI Jurusan IPS Di SMAN Karubaga Kabupaten Tolikara," Jurnal Penelitian dan Pendidikan IPS 9, no. 2 (2015): 1170-1180,

http://ejournal.unikama.ac.id/index.php/JPPI/article/download/ $1666 / 1345$.

${ }^{8}$ S. Nasution, Teknologi Pendidikan (Jakarta: Bumi Aksara, 2011).

${ }^{9}$ S. Nasution, Teknologi Penddikan (Jakarta: Bumi Aksara, 2011). 
pembelajaran. Informasi yang terkandung dalam media harus dapat melibatkan siswa, baik mental maupun dalam bentuk kegiatan nyata, agar pembelajaran dapat berlangsung. Materi diatur lebih sistematis dan psikologis dan divisualisasikan pada dasarnya untuk menciptakan instruksi pembelajaran yang efektif. Untuk itu, media pembelajaran harus dapat memberikan pengalaman yang menyenangkan dan memenuhi kebutuhan individu siswa, karena setiap siswa memiliki kemampuan yang berbeda-beda. ${ }^{10}$

Media pembelajaran sangatlah berpengaruh dalam mencapai tujuan pembelajaran, karena media pembelajaran sangat penting dalam membantu guru menyampaikan materi. Oleh karena itu, pendidik perlu memilih dan menetapkan media pembelajaran dalam proses balajar mengajar. Namun realita, penggunaan media pembelajaran seringkali diabaikan oleh guru dengan alasan waktu dalam membuat media pembelajaran membuat persiapan mengajar sangat terbatas.

Pada tahun 1946, Edgar Dale mengembangkan teorinya tentang Cones of Experience (kerucut pengalaman Dale). Ini adalah representasi visual dari jenis pengalaman yang dihadapi manusia saat mereka bersiap untuk mensintesis pengetahuan dan mengubahnya menjadi pemahaman (Gambar 1). ${ }^{11}$ Dale menyebutkan bahwa manusia dapat menghadapi berbagai jenis pengalaman. Setiap tingkat pengalaman menghasilkan tingkat efektivitas yang berbeda karena bergantung pada proses pengetahuan. Dia telah membagi modelnya menjadi tiga kategori utama; paling abstrak ke yang paling abstrak, karena bergerak turun dari atas ke bawah. Menurut Dale, pengaturan dalam kerucut didasarkan pada abstraksi dan kuantitas indera yang terlibat. Pengalaman di setiap tahap dapat dicampur dan saling terkait yang memunculkan pembelajaran yang lebih bermakna. Teori ini menjadi dasar teoretis penggunaan media dalam proses pembelajaran. ${ }^{12}$

Dalam proses belajar mengajar seringkali dijumpai sebagian dari peserta didik tidak memahami materi ajar, karena guru di sekolah sangat jarang menggunakan media pembelajaran.

\footnotetext{
${ }^{10}$ Cecep Kuatandi and Bambang Sutjipto, Media Pembelajaran Manual Dan Digital, ed. Risman Sikumbang, 2nd ed. (Bogor: Ghalia Indonesia, 2013).

${ }^{11}$ Edgar Dale, Audio-Visual Methods in Teaching, 3rd ed. (New York: The Dryden Press, 1969).

${ }^{12}$ Daryanto, Media Pembelajaran: Peranannya Sangat Penting Dalam Mencapai Tujuan Pembelajaran (Yogyakarta: Gava Media, 2013), 51.
}

Situasi ini semakin diperburuk oleh metode pembelajaran konvensional yang diterapkan guru. Fasilitas belajar yang tersedia di sekolah masih sangat minim, akibatnya proses pembelajaran kurang efektif, tidak menyenangkan dan bermakna. Dalam hal ini guru terbatas dalam menyajikan materi pelajaran dengan hanya menggunakan bukubuku pelajaran sebagai sumber dan satu-satunya media pembelajaran.

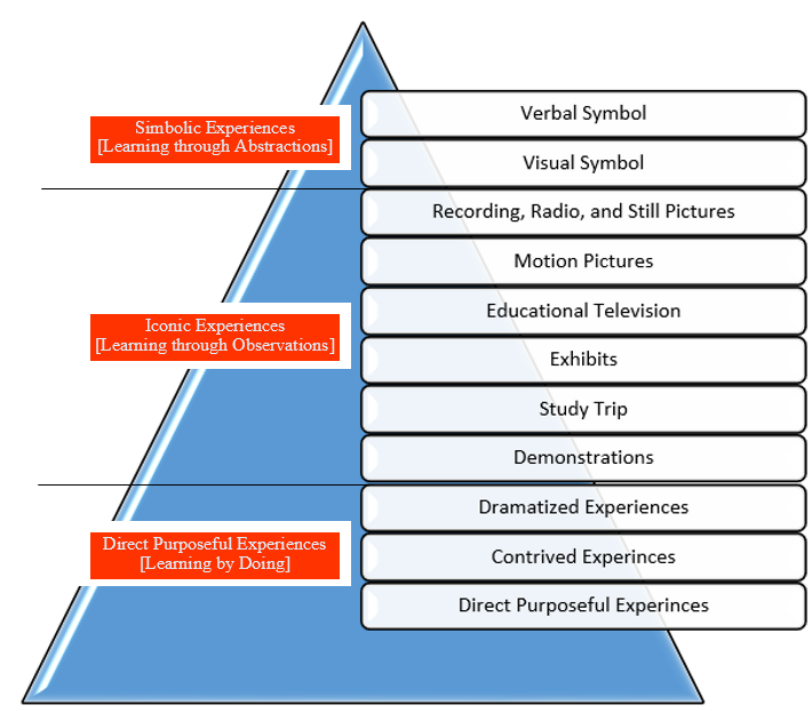

Gambar 1. Diadaptasi dari Dale's Cone of Experience ${ }^{13}$

Minimnya kreativitas guru dalam menggunakan media pembelajaran, juga penulis temukan di lokasi penelitian yakni di SD Negeri 075082 Marafala, khususnya pada mata pelajaran Pendidikan Agama Kristen (PAK). Di sekolah ini, kualitas belajar mengajar masih belum baik, para guru masih mengandalkan metode konvensional dalam pengajarannya dan teacher-centered learning. Lebih lanjut, ditemukan juga - para guru hanya memanfaatkan ruangan kelas sebagai pusat proses belajar mengajar. Guru kurang mampu dalam mengelola kelas sehingga dari tahun ke tahun tidak ada perubahan baik dalam pengaturan kelas maupun tempat duduk siswa, di sisi lain kelas yang bersih dan nyaman dapat meningkatkan minat belajar siswa. Fasilitas yang terbatas serta sumbersumber yang kurang memadai ini menyebabkan guru-guru terbatas dalam menyelenggarakan proses pembelajaran dalam derajat mutu yang baik.

Beberapa temuan penelitian sebelumnya mengindakasi bahwa setiap orang pada prinsipnya memiliki bakat kreatif dan kemampuan untuk mengekspreikan dirinya secara kreatif, meskipun masing-masing dalam disiplin dan kadar yang

\footnotetext{
${ }^{13}$ Dale, Audio-Visual Methods in Teaching.
} 
berbeda-beda. Indikator kreativitas dapat dilihat dari 4 aspek, yakni "(1) pribadi adalah yang mencerminkan orisinalitas dari individu tersebut. Dari ungkapan pribadi yang unik inilah dapat diharapkan timbulnya ide-ide baru dan produkproduk yang inovatif; (2) pendorong yaitu lingkungan yang mendukung, tetapi dapat pula terhambat dalam lingkungan yang tidak menunjang; (3) proses kreativitas dilihat dari empat tahapan yaitu persiapan, inkubasi, iluminasi, verifikasi; dan (4) produk yaitu kondisi yang memungkinkan seseorang menciptakan produk kreatif yang bermakna." 14

Kemudian, Supriadi mengemukakan indikator kreativitas yaitu "(1) terbuka dalam pengalaman baru, (2) toleransi terhadap perbedaan pendapat dan situasi yang tidak pasti, (3) percaya diri dan mandiri (4) tekun dan tidak mudah bosan (5) mempunyai kesadaran etik, moral dan estetik yang baik."15 Selanjutnya menurut Koswara \& Halimah indikator kreativitas yaitu "(1) pengetahuan yang luas (2) kemauan yang keras untuk mencapai suatu tujuan (3) energetik atau semangat kerja yang tinggi (4) konsentrasi atau kemampuan memusatkan pikiran."16

James C. \& Hammer dalam Sumiyantiningsih, mengatakan bahwa "kreativitas adalah berpikir yang menghasilkan cara-cara baru, konsep baru, pengertian baru, penemuan baru, dan karya seni yang baru." Sementara menurut Mednick, kreativitas adalah "suatu kemampuan untuk membuat kombinasi baru berdasarkan data, informasi, atau unsur-unsur yang ada menjadi sesuatu yang bermakna."17

Adapun yang menjadi prinsip yang dapat dilakukan dalam mengembangkan kreativitas adalah "(a) bersedia untuk mencoba hal-hal yang baru; (b) mendesain lingkungan yang kreatif; (c) memiliki curiosity and interest (rasa ingin tahu dan minat); (d) berusaha untuk tertarik pada setiap hal setiap hari; (e) berusaha untuk mencari pemecahan alternatif; (f) mengembangkan minat pada pengetahuan di bidang yang dinginkan; serta (g)

\footnotetext{
${ }^{14}$ Munandar Utami, Pengembangan Kreativitas Anak Berbakat (Jakarta: Rineka Cipta, 2016), 45.

${ }^{15}$ Supriadi, Strategi Belajar Mengajar (Bandung: Alfabeta, 2011), 61.

${ }^{16}$ D. Deni Koswara and Halimah, Bagaimana Menjadi Guru Kreatif? (Bandung: Pribumi Mekar, 2008), 48.

${ }^{17}$ Dien Sumiyantiningsih, Mengajar Dengan Kreatif \& Menarik, 3rd ed. (Yogyakarta: ANDI, 2006).
}

membiasakan diri untuk melakukan aktivitas yang autentik." 18

Selanjutnya Hamalik dalam Rasam dan Sari mengemukakan bahwa "pemakaian media pembelajaran dalam proses belajar mengajar dapat membangkitkan keinginan dan minat yang baru, membangkitkan motivasi dan rangsangan kegiatan belajar, dan juga membawa pengaruh-pengaruh yang baik bagi peserta didik dalam belajar." 19 Setiap peserta didik tentunya menginginkan pembelajaran yang menyenangkan.

Berangkat dari uraian di atas, dalam penelitan ini penulis menyelidiki kreativitas guru dalam pembelajaran terutama menyangkut pengembangan dan penggunaan media pembelajaran. Dengan demikian, yang menjadi tujuan penelitian adalah untuk (1) mendeskripsikan kreativitas guru dalam mengembangkan dan menggunakan media pembelajaran, (2) menjelaskan faktor-faktor penyebab rendahnya kreativitas guru dalam mengembangkan media pembelajaran, serta (3) untuk menjelaskan upaya yang perlu ditempuh dalam meningkatkan kreativitas penggunaan media pembelajaran PAK.

\section{Metode}

Penelitian ini mengambil lokasi di SD Negeri 075082 Marafala dengan alamat Jl. Pendidikan, Desa Marafala, Kecamatan Lahewa, Kabupaten Nias Utara. Menggunakan jenis penelitian deskriptif dengan pendekatan kualitatif, yakni penelitian yang bermaksud untuk memahami fenomena tentang apa yang dialami oleh subjek penelitian. ${ }^{20}$ Sumber data dan informan (partisipan) terdiri dari guru mata pelajaran Pendidikan Agama Kristen dan kepala sekolah. Data dikumpulkan dengan menggunakan teknik wawancara semi terstruktur $^{21}$ dan observasi. ${ }^{22}$ Analisis data dilakukan dengan menggunakan interactive model

\footnotetext{
${ }^{18}$ Ibid.

${ }^{19}$ Fadli Rasam and Ani Interdiana Candra Sari, "Peran
} Kreativitas Guru Dalam Penggunaan Media Belajar Dan Minat Belajar Dalam Meningkatkan Prestasi Belajar Peserta Didik SMK Di Jakarta Selatan," Research and Development Journal of Education 5, no. 1 (2018): 97, https://journal.lppmunindra.ac.id/index.php/RDJE/article/view/ 3391.

${ }^{20}$ Lexy J. Moleong, Metodologi Penelitian Kualitatif (Bandung: Remaja Rosdakarya, 2017).

${ }^{21}$ H Russell Bernard and Bernard H. Russell, Research Methods in Anthropology: Qualitative and Quantitative Approaches (Walnut Creek: AltaMira Press, 2006).

${ }^{22}$ Brigitte Smit and Anthony J. Onwuegbuzie, "Observations in Qualitative Inquiry: When What You See Is Not What You See," International Journal of Qualitative Methods 17, no. 1 (December 2018). 
yang dikembangkan oleh Miles dan Huberman yang secara umum digunakan dalam penelitian kualitatif, teknik ini mencakup tiga proses yakni: (a) pengumpulan dan kondensasi (reduksi) data; (b) penyajian data; (c) verikasi data dan/atau penarikan kesimpulan. ${ }^{23}$ Analisis data dilakukan selama penelitian berlangsung. ${ }^{24}$

\section{Hasil dan Pembahasan}

a. Pelaksanaan Pembelajaran PAK di SD Negeri 075082 Marafala

Berdasarkan hasil pengamatan yang telah penulis lakukan, ditemukan bahwa bahwa guru PAK dalam melaksanakan proses belajar mengajar di kelas tidak menggunakan media pembelajaran. Meskipun kesiapan guru cukup baik, namun dalam pemanfaatan media pembelajaran, kreativitas guru masih tergolong rendah. Kreativitas yang rendah ini disebabkan oleh keterbatasan-keterbatasan dalam sarana dan fasilitas yang dimiliki oleh sekolah. Keadaan ini semakin diperburuk oleh sikap guru yang tidak berani mengambil risiko, tidak mau berusaha dan bertindak, malas berpikir, dan lain sebagainya.

Selain temuan di atas, penulis juga menemukan bahwa guru-guru hanya memanfaatkan buku sebagai media dan tidak memanfaatkan media lain dalam proses pembelajaran. Akibatnya, peserta didik kurang tertarik pada materi yang disajikan, tidak terlibat aktif baik fisik maupun psikis, jenuh, keluar masuk ruangan, dan juga hasil belajar siswa kurang memuaskan.

Temuan lainnya adalah guru masih menggunakan KTSP dengan alasan sekolah belum memiliki sumber-sumber belajar yang memadai untuk menerapkan Kurikulum 2013. Partisipasi dan keterlibatan peserta didik selama proses pembelajaran masih sangat rendah, mereka lebih banyak diam dan mendengar penjelasan guru tanpa aktivitas belajar lainnya. Hal ini terjadi karena metode mengajar guru tidak bervariasi, guru lebih mengandalkan metode ceramah tanpa diselingi oleh metode lain yang lebih efektif dan efisien. Pembelajaran berlangsung selalu berpusat kepada guru (teacher-centered learning).

${ }^{23}$ Matthew B. Miles, A. Michael Huberman, and Johnny Saldaña, Qualitative Data Analysis: A Methods Sourcebook, 3rd ed. (New York, NY: SAGE Publications, Inc., 2014), 3133.

${ }^{24}$ John W Cresswell, Research Design: Qualitative, Quantitative, and Mixed Methods Approaches, Research Design, Second Edition, 4th ed. (SAGE Publications, Inc., 2014). b. Kreativitas Guru dalam Menggunakan Media Pembelajaran

Hasil wawancara yang dilakukan kepada partisipan, diperoleh informasi bahwa kreativitas guru dalam mengembangkan dan menggunakan media pembelajaran pada semua materi ajar di SD Negeri 075082 Marafala masih tergolong rendah. Hal ini disebabkan oleh karena guru-guru hanya fokus pada materi esensial tetapi kurang membuat anak mudah memahaminya. Mereka tidak menggunakan media sebagai alat bantu pembelajaran. Data ini sejalan dengan hasil observasi - guru hanya menyampaikan materi begitu saja tanpa memerhatikan kemudahan bagi peserta didik guna memahami materi ajar. Keseluruhan responden menyatakan bahwa kreativitas guru di SD Negeri 075082 Marafala masih kurang.

Selanjutnya, sebagai seorang guru profesional mestinya mampu menghasilkan berbagai cara atau ide dalam memecahkan masalah yang terkait dengan penggunaan media pembelajaran yakni "merancang dan mengembangkannya sendiri dengan menggunakan bahan-bahan yang ada di sekitar sekolah" dan "menggunakannya pada tiaptiap kegiatan belajar-mengajar agar peserta didik lebih mudah mengerti dan memahami materi pelajaran - namun hal itu tidak terjadi" [Halawa \& Zendrato, 28/4].

Media pembelajaran sangat berperan dalam kegiatan belajar mengajar, dan "guru harusnya mampu mengetahui bagaimana merancang, mengembangkan dan memanfaatkan media pembelajaran, sehingga nantinya proses belajar mengajar dapat lebih efektif dan menyenangkan" [Nazara, 29/4]. Di sisi lain, sekolah ini "tidak memiliki fasilitas yang memadai untuk mendukung proses pembelajaran, guru hanya menggunakan buku yang terkait dengan materi ajar, dan tidak menggunakan media pada saat menyelenggarakan proses pembelajaran di kelas" [Halawa, 28/4].

Fasilitas belajar termasuk alat bantu (media), sangat minim bahkan sekolah ini hampir tidak memilikinya, kecuali meja-kursi dan papan tulis. Dalam hal pengembangan media pembelajaran "mestinya sekolah berupaya menyediakan media pembelajaran atau alat-alat dan bahan ajar. Lalu, sekolah juga perlu memberi kesempatan kepada guru untuk mengikuti pelatihan atau workshop terkait dengan pengembangan media pembelajaran" [Halawa \& Zendrato, 28-29/4]. 
c. Faktor-faktor Penyebab Rendahnya Kreativitas Guru dalam Menggunakan Media pembelajaran

Berdasarkan wawancara dengan respoden, diperoleh informasi bahwa penyebab rendahnya kreativitas guru dalam mengembangkan dan menggunakan media dalam proses pembelajaran, di antaranya pertama, "fasilitas belajar yang dimiliki oleh sekolah sangat terbatas, demikian halnya sumber belajar, dan semakin diperparah oleh internet di lokasi sekolah sangat buruk" [Nazara, 29/4]. Kedua, "para guru tidak mengambil risiko, yang timbul atas inisiatif mengembangkan secara mandiri media pembelajaran - berupa pembiayaan" [Halawa, 28/4]. Ketiga, "sumber daya listrik sangat buruk, sebentar mengalir - padam lama kemudian" [Zendrato, 29/4]

Ketika ditanya, apa upaya yang ditempuh untuk mengatasi masalah tersebut, "kami telah dan akan menyampaikan kembali kepada kepala sekolah agar ketiadaan fasilitas-fasilitas sekolah ini dapat segera diangsur-angsur melengkapinya" [Halawa, 28/4]. "Guru mestinya mengambil inisiatif dan aktif mencari dan menemukan sumber-sumber yang dapat dijadikan sebagai alat bantu pembelajaran termasuk teknik-teknik sederhana tentang merancang dan mengembangkan media" [Zendrato, 28/4].

Hasil penelitian sebagaimana dijelaskan di atas, menunjukkan bahwa kreativitas guru dalam penggunaan media pembelajaran masih tergolong rendah. Di sisi lain, penggunaan media ini dalam pembelajaran memiliki peran penting untuk menunjang keberhasilan proses belajar mengajar sehingga kegiatan belajar mengajar dapat berlangsung secara efektif termasuk dalam memenuhi tujuan pembelajaran PAK.

Selanjutnya, guru PAK masih menggunakan Kurikulum Tingkat Satuan pendidikan (KTSP), bukan Kurikulum 2013. Ini disebabkan oleh sumber belajar seperti buku pegangan guru belum tersedia di SD Negeri Negeri 075082 Marafala; di lain sisi para guru kurang inisiatif untuk mencari dan menemukannya sendiri. Hal ini bertolak belakang dengan kebijakan pemerintah yang mensyaratkan penggunaan Kurikulum 2013 dalam proses pembelajaran termasuk pada mata ajar Pendidikan Agama Kristen. Seorang guru yang profesional harus bisa menggunakan kurikulum mutakhir dalam pembelajaran, terlebih-lebih kemampuan dalam berkreativitas dan komunikasi menjadi sangat penting. ${ }^{25}$

Penggunaan Kurikulum 2013 menuntut kreativitas dan komunikasi dalam proses pembelajaran kepada peserta didik. Kompetensi ini "dirancang untuk dicapai melalui proses pembelajaran berbasis penemuan (dicovery learning) melalui kegiatan-kegiatan berbentuk tugas (project based learning) yang mencakup proses-proses mengamati, menanya, mencoba, menalar, dan mengkomunikasikan."26

Rendahnya kreativitas guru dalam memanfaatkan media pembelajaran, semakin diperburuk oleh rendahnya kreativitas guru dalam menggunakan metode mengajar yang bervariasi. Guru PAK masih mengajar dengan metode konvensional seperti ceramah; tanpa dukungan alat bantu atau media pembelajaran. Hal ini tampak pada RPP yang telah disusun oleh guru, metode mengajar yang mereka gunakan hanya metode ceramah.

Seorang guru yang kreatif harus dapat memikirkan bagaimana caranya agar materi yang disampaikan dapat dimengerti dan dipahami oleh peserta didik, guru yang kreatif akan selalu berpikir untuk membawa alat peraga atau media pembelajaran setiap kali masuk ke ruang kelas. Hamalik dalam Rasam dan Sari, mengatakan bahwa "pemakaian media pembelajaran dalam proses belajar mengajar dapat membangkitkan keinginan dan minat yang baru, membangkitkan motivasi dan rangsangan kegiatan belajar, dan juga membawa pengaruh-pengaruh yang baik bagi peserta didik dalam belajar.",27

\section{d. Upaya Meningkatkan Kreativitas Guru dalam Mengembangkan dan Menggunakan Media Pembelajaran}

Rendahnya kreativitas guru dalam mengembangkan dan menggunakan media pembelajaran sebagaimana dijelaskan di atas, terutama disebabkan oleh pertama, ketersediaan sarana dan fasilitas

${ }^{25}$ Andar Gultom, Profesionalisme, Standar Kompetensi, Dan Pengembangan Profesi Guru PAK, ed. Saur Hasugian, 1st ed. (Bandung: Bina Media Informasi, 2007), 24.

${ }^{26}$ Hamad Ibnu; Komarudin; Mohandas Ramon; Sumadi Tjipto, Kurikulum 2013 : Tanya Jawab Dan Opini (Jakarta: Pusat Informasi dan Hubungan Masyarakat (PIH) Kementerian Pendidikan dan Kebudayaan, 2013), 4-9.

${ }^{27}$ Rasam and Sari, "Peran Kreativitas Guru Dalam Penggunaan Media Belajar Dan Minat Belajar Dalam Meningkatkan Prestasi Belajar Peserta Didik SMK Di Jakarta Selatan." 
pendukung penyelenggaraan pembelajaran seperti jaringan internet dan sumber daya listrik. Kedua, media pengajaran yang sangat minim, dan ketiga, hambatan dalam diri guru itu sendiri, berupa keinginan untuk mencoba hal-hal yang baru, rasa ingin tahu dan minat, serta usaha mencari pemecahan alternatif.

Kreativitas guru dalam mengembangkan dan memanfaatkan media dalam pembelajaran tentu saja dipengaruhi oleh faktor-faktor tersebut di atas, karena hal itu sudah menyangkut komponen penting dalam penyelenggaraan pendidikan. Namun, meskipun fasilitas dan sumber-sumber belajar tersedia secara memadai ataupun sebaliknya, seorang guru tetap saja harus memiliki nilai-nilai yang harus dipegang teguh sebagai seorang profesional berupa kreativitas, komitmen, optimisme serta keberpihakan kepada peserta didik, termasuk dalam menghadapi berbagai masalah dan tantangan.

Hingga penelitian ini dilaksanakan, sekolah dan para guru belum memiliki upaya untuk meningkatkan kreativitas dalam penggunaan media pembelajaran di SD Negeri 075082 Marafala. Idealnya, seorang guru harus berusaha melaksanakan proses pembelajaran dengan memberikan kemudahan bagi peserta didik untuk mengembangkan potensi yang dimilikinya. Karena itu, guru perlu menciptakan suasana pembelajaran yang kreatif dan menyenangkan, sehingga proses belajar mengajar terhadap peserta didik dapat berjalan dengan baik. $^{28}$ Kreativitas seorang guru dipengaruhi oleh kebebasan dalam melihat dan bertindak, komitmen, kerja keras, lingkungan yang kondusif. Sebaliknya, kreativitas akan terhambat bila guru malas berpikir, melakukan sesuatu, impulsif, menganggap remeh karya orang lain, mudah putus asa dan tidak tahan uji. ${ }^{29}$

Usaha seorang guru dalam melaksanakan proses belajar mengajar di dalam kelas harus memiliki pengaruh positif terhadap peserta didik. Guru yang kreatif tentunya memiliki motivasi yang kuat dalam dirinya, termasuk dalam menggunakan media pembelajaran, terlebih-lebih pada mata pelajaran Pendidikan Agama Kristen, guru PAK bukan hanya dituntut untuk mengajar saja tetapi guru PAK juga harus bisa menjadi seorang yang mempunyai kepribadian yang baik dalam

${ }^{28}$ E. Mulyasa, Menjadi Guru Profesional, ed. Mukhlis, 11th ed. (Bandung: PT Remaja Rosdakarya, 2011), 69.

${ }^{29}$ Ngainun Naim, Menjadi Guru Inspiratif: Memberdayakan Dan Mengubah Jalan Hidup Siswa (Yogyakarta: Pustaka Pelajar, 2009), 245. mengarahkan peserta didik ke arah yang lebih baik. Keberhasilan suatu proses pembelajaran adalah ketika seorang pendidik sungguh-sungguh melaksanakan tugasnya dengan baik dan mampu berpikir kritis serta memiliki kreativitas yang baik. Oleh sebab itu, sebagai pendidik harus dapat mengembangkan dan menggunakan media dalam proses belajar mengajar.

Secara umum ada 4 jenis media pembelajaran yang dapat dikembangkan yaitu media audio, media visual, media audio-visual, dan multi-media. ${ }^{30}$ Keempat jenis media pembelajaran ini akan dijelaskan sebagai berikut, pertama - "media visual yaitu jenis media yang digunakan hanya mengandalkan indera penglihatan semata-mata dari peserta didik. Dengan media ini pengalaman belajar yang dialami peserta didik sangat tergantung pada kemampuan penglihatannya. Kedua, media audio adalah jenis media yang digunakan dalam proses pembelajaran dengan hanya melibatkan indera pendengaran peserta didik. Pengalaman belajar yang didapatkan adalah dengan mengandalkan indera kemampuan pendengaran. Ketiga, media audio-visual adalah jenis media yang digunakan dalam kegiatan pembelajaran dengan melibatkan pendengaran dan penglihatan sekaligus dalam satu proses atau kegiatan. Pesan dan informasi yang dapat disampaikan melalui media ini berupa pesan verbal dan nonverbal yang mengandalkan baik penglihatan maupun pendengaran. Keempat, multimedia yaitu media yang melibatkan beberapa jenis media dan peralatan secara terintegrasi dalam suatu proses atau kegiatan pembelajaran. Pembelajaran multimedia melibatkan indera penglihatan dan pendengaran melalui media teks, visual diam, visual gerak, dan audio serta media interaktif berbasis komputer dan TIK." 31

Multimedia telah menjadi elemen penting dalam desain instruksional. Didefinisikan sebagai penyajian materi menggunakan kata-kata dan gambar, untuk mempromosikan pembelajaran. ${ }^{32}$ Orang-orang (peserta didik) akan orang belajar lebih baik dari kata-kata dan gambar daripada dari kata-kata saja. $^{33}$ Multimedia digunakan untuk

\footnotetext{
${ }^{30}$ Azhar Arsyad, Media Pembelajaran (Jakarta: PT Raja Grafindo Persada, 2013).

${ }^{31}$ Naim, Menjadi Guru Inspiratif: Memberdayakan Dan Mengubah Jalan Hidup Siswa.

${ }^{32}$ Richard E. Mayer, Multimedia Learning, 3rd ed. (New York: Cambridge University Press, 2020).

${ }^{33}$ J. D. Fletcher and Sigmund Tobias, "The Multimedia Principle," in The Cambridge Handbook of Multimedia Learning (Cambridge University Press, 2005), 117-134, https://www.cambridge.org/core/product/identifier/CBO97805 11816819A015/type/book_part.
} 
mengomunikasikan konsep-konsep kompleks secara efektif. Menjadi lebih mudah untuk mengembangkan dan menggunakan teknologi multimedia karena kemajuan dalam perangkat keras dan lunak. Multimedia dapat merujuk pada modalitas sensorik seperti teks vs narasi, mode representasional seperti grafis vs teks, atau media pengiriman seperti kertas vs computer. ${ }^{34}$

Untuk meningkatkan kualitas penyampaian informasi dalam proses belajar-mengajar diperlukan media pembelajaran. Karena itu, sebelum membuat media pembelajaran, beberapa kriteria harus diperhatikan dalam memilih media pembelajaran agar proses belajar-mengajar berjalan lancar dan mengikuti tujuan yang ditetapkan, yakni pertama, "mengikuti tujuan - media pembelajaran harus dipilih berdasarkan tujuan instruksional, yaitu domain kognitif, afektif, dan psikomotorik. Kedua, praktis, fleksibel, dan bertahan lama - media pembelajaran tidak selalu mahal dan berbasis teknologi. Memanfaatkan lingkungan dan sesuatu yang sederhana namun efektif akan lebih efektif daripada media pembelajaran yang mahal dan rumit. Ketiga, mampu dan terampil untuk menggunakan - nilai dan manfaat media pembelajaran ditentukan terutama oleh bagaimana guru menggunakan media ini. Keterampilan menggunakan media pembelajaran juga dapat diturunkan kepada siswa sehingga siswa dapat dengan terampil menggunakan media pembelajaran yang dipilih. Keempat, kondisi siswa - kriteria untuk memilih media yang sesuai disesuaikan dengan keadaan siswa, baik kebutuhan psikologis, filosofis, maupun sosiologis anak, karena media yang tidak mengikuti keadaan siswa tidak akan banyak membantu dalam memahami materi pembelajaran. Kelima, ketersediaan - meskipun media dianggap sangat tepat untuk mencapai tujuan pembelajaran, media tidak dapat digunakan jika tidak tersedia bila diperlukan untuk memenuhi kebutuhan siswa dan guru." 35

Kembali ke masalah kreativitas guru dalam mengembangkan media pembelajaran. Minimnya kreativitas guru dalam mengembangkan media pembelajaran merupakan masalah serius, serta merupakan persoalan yang sering ditemukan di lembaga-lembaga pendidikan di wilayah pelosok negeri dalam konteks Indonensia. Tentu saja, untuk mengatasi persoalan ini secara bertahap, diperlukan

${ }^{34}$ Richard. E. Mayer and Roxana Moreno, “Animation as an Aid to Multimedia Learning," Educational Psychology Review 14, no. 1 (2002): 87-99,

https://link.springer.com/article/10.1023/A:1013184611077.

${ }^{35}$ Arsyad, Media Pembelajaran, 74. kontribusi dari berbagai pihak. Karena itu, pada kesempatan ini penulis merekomendasi ulang halhal berikut sebagai bahan atau masukan bagi institusi pendidikan khususnya di SD Negeri 075082 Marafala, yakni:

\section{Bagi kepala sekolah}

- Kepala sekolah sebagai penanggung jawab penyelenggaraan pendidikan di tingkat satuan pendidikan memiliki tanggung jawab mengembangkan fasilitas pendidikan termasuk di dalamnya media pembelajaran. Ketidakstabilan aliran listrik dan jaringan internet di SD Negeri 075082 Marafala dapat diatasi melalui pengadaan generator set dan repeater (alat penguat sinyal) secara legal (dengan ijin). Peralatan dan perlengakapan dimaksud dapat dibiayai dari dana yang bersumber dari dana operasional sekolah; dan atau melalui dukungan komite sekolah.

- Kepala sekolah perlu memberi perhatian terhadap peningkatan keahlian dan kompetensi para guru. Hal ini dapat ditempuh dengan mengikutsertakan guruguru pada tiap-tiap pelatihan atau workshop yang diselenggarakan oleh dinas pendidikan dan/atau lembaga tertentu.

- Menyelenggarakan sendiri pelatihan atau workhsop di tingkat sekolah bekerjasa sama dengan sekolah-sekolah lain; dengan mengundang instruktur untuk melatih para guru meningkatkan kompetensinya termasuk dalam hal pengembangan media pembelajaran.

\section{Bagi guru}

Temuan penelitian menunujukkan bahwa minimnya kreativitas guru dalam mengembangkan media pembelajaran salah satunya disebabkan oleh hambatan dalam diri guru berupa keinginan untuk mencoba hal-hal yang baru, rasa ingin tahu dan minat, serta usaha mencari pemecahan alternatif. Untuk mengatasi hal ini, guru perlu merenungkan kembali panggilannya sebagai pendidik, yakni berbakti membimbing anak didik seutuhnya menjadi manusia yang memiliki pengetahuan, terampil melakukan, berkepribadian serta mampu hidup bersama secara damai dalam lingkup masyarakat luas.

Sebagai guru dalam perpektif Kristen, mengajar adalah "panggilan atau pelayanan dengan tujuan memperlengkapi para murid bagi pekerjaan pelayanan (Efesus 4:12); dan hendaklah 
mengerjakan panggilan ini dengan segenap hati seperti bekerja untuk Tuhan dan bukan untuk yayasan atau dewan sekolah atau bahkan untuk murid-murid kita (Kolose 3:23)." ${ }^{36}$ Setiap guru harus memiliki spirit ini, "membuka jalan bagi peserta didik menuju kerohanian melalui pembentukan karakter, moral dan sosial yang sempurna adalah esensi menjadi guru pendidikan agama Kristen." 37

Terkait dengan peningkatan kreativitas dalam mengembangkan dan memanfaatkan media dalam pembelajaran, maka guru perlu:

- Meningkatkan kompetensinya secara mandiri, serta mengikuti berbagai pelatihan yang diselenggarakan oleh berbagai lembaga/instansi.

- Membangun relasi dan kolaborasi dengan rekan sejawat dalam mengembangkan media pembelajaran.

- Melibatkan peserta didik dalam merancang dan mengembangkan media pembelajaran

- Guru harus meningkatkan inisiatif dan kreativitas dalam membuat media agar pembelajaran lebih kreatif, menyenangkan, bermakna serta materi dapat lebih mudah dicerna dan dipahami oleh peserta didik.

Yesus dalam pengajaran-Nya "menggunakan objek yang ada di sekitar-Nya sebagai media berupa benda-benda yang ada di alam dan bahkan juga manusia (murid atau orang yang mendengar pengajaran-Nya). Alkitab Perjanjian Baru menampilkan sosok Yesus Sang Guru Agung memberi teladan dan panutan dalam mengajar dengan efektif dan efisien. Yesus adalah sosok guru yang datang dari Allah (Yoh. 3:2)." guru yang menggunakan metode yang kreatif dan kontekstual. Ia menggunakan pengalaman hidup para pendengar-Nya untuk menyampaikan pesan yang hendak disampaikan-Nya. Sebagai guru, "Yesus mempunyai sasaran dan metode-metode untuk mencapai sasaran itu. Dengan berbagai

${ }^{36}$ Jossapat Hendra Prijanto, "Panggilan Sebagai Guru Kristen Wujud Amanat Agung Yesus Kristus Dalam Penanaman Nilai Alkitabiah Pada Era Digital [A Christian Teacher's Calling in Response to Jesus Christ's Great Commission in Instilling Biblical Values in a Digital Era]," Polyglot: Jurnal Ilmiah 13, no. 2 (August 2017): 13.

${ }^{37}$ Delipiter Lase and Etty Destinawati Hulu, "Dimensi Spritualitas Dalam Kompetensi Kepribadian Guru Pendidikan Agama Kristen," SUNDERMANN: Jurnal Ilmiah Teologi, Pendidikan, Sains, Humaniora dan Kebudayaan 13, no. 1 (March 20, 2020): 13-25,

https://jurnal.sttsundermann.ac.id/index.php/sundermann/article /view/24.

${ }^{38}$ Yesi Tamara et al., "Profesionalitas Yesus Sang Guru Agung Dalam Penggunaan Media Pembelajaran," Didache: Journal of Christian Education 1, no. 1 (June 2020): 65. ilustrasi, metode, media dan situasi bahkan tempat, dan Yesus berhasil menyampaikan pesan-Nya melalui pengajaran." 39

Dalam pengajaran-Nya, "Tuhan Yesus menggunakan domba (Mat. 18:12-14 dan Luk. 15:3-7), uang (Mrk. 12:41-44, Luk. 21:1-4), pohon anggur (Yoh. 15:1-8), tanah dan benih (Mat. 13:123), dasar bangunan (Mat. 7:24-27 dan Luk. 6:4749), pukat (Mat. 13:47-50) dan apapun yang ada di sekitar lingkungan para pendengar-Nya untuk dijadikan bahan pengajaran. Tuhan Yesus menggunakan media yang dapat dilihat dengan konkrit sehingga dapat menolong pendengar memahami pesan dengan cepat. ${ }^{\prime 40}$

\section{Konklusi}

Hasil penelitian menunjukkan bahwa kreativitas guru dalam pengembangan dan penggunaan media pembelajaran masih tergolong rendah. Di sisi lain, penggunaan media ini dalam pembelajaran memiliki peran penting untuk menunjang keberhasilan proses belajar mengajar. Rendahnya kreativitas guru dalam mengembangkan dan menggunakan media pembelajaran disebabkan oleh terbatasnya sarana dan fasilitas pendukung penyelenggaraan pembelajaran, serta hambatan dalam diri guru itu sendiri.

Karena itu, sekolah perlu mengembangkan fasilitas pendidikan secara bertahap termasuk di dalamnya media pembelajaran. Sekolah juga perlu memberi perhatian terhadap peningkatan keahlian dan kompetensi para guru melalui pelatihan dan atau menyelenggarakan sendiri pelatihan bagi guru dengan mengundang instruktur terlatih. Para guru perlu meningkatkan kompetensinya secara mandiri, serta membangun relasi dan kerjasama dengan rekan sejawat dan bahkan melibatkan peserta didik dalam merancang dan mengembangkan media pembelajaran.

\section{Ucapan Terima Kasih}

Penelitian ini tentunya akan sulit diselesaikan tanpa dukungan dari berbagai pihak. Karena itu, pada kesempatan ini penulis menyampaikan terimakasih kepada Kepala Sekolah dan juga guru-guru PAK di SD Negeri 075082 Marafala. Mereka telah mendukung penelitian ini dalam bentuk penyediaan data yang diperlukan.

\footnotetext{
${ }^{39}$ Ibid.

${ }^{40}$ Harianto GP, Teologi PAK: Metode Dan Penerapan Pendidikan Kristen Dalam Alkitab (Yogyakarta: ANDI, 2017), 471.
} 


\section{Referensi}

Ambarjaya, Beni S., and Elin Marlina. Model-Model Pembelajaran Kreatif. 1st ed. Bogor: Regina Publishing and Printing, 2008.

Andar Gultom. Profesionalisme, Standar Kompetensi, Dan Pengembangan Profesi Guru PAAK. Edited by Saur Hasugian. 1st ed. Bandung: Bina Media Informasi, 2007.

Arsyad, Azhar. Media Pembelajaran. Jakarta: PT Raja Grafindo Persada, 2013.

Cresswell, John W. Research Design: Qualitative, Quantitative, and Mixed Methods Approaches. Research Design, Second Edition. 4th ed. SAGE Publications, Inc., 2014.

Dale, Edgar. Audio-Visual Methods in Teaching. 3rd ed. New York: The Dryden Press, 1969.

Daryanto. Media Pembelajaran: Peranannya Sangat Penting Dalam Mencapai Tujuan Pembelajaran. Yogyakarta: Gava Media, 2013.

Departemen Pendidikan Nasional. Kamus Besar Bahasa Indonesia. 4th ed. Jakarta: PT Gramedia Pustaka Utama, 2008.

E. Mulyasa. Menjadi Guru Profesional. Edited by Mukhlis. 11th ed. Bandung: PT Remaja Rosdakarya, 2011.

Fletcher, J. D., and Sigmund Tobias. "The Multimedia Principle." In The Cambridge Handbook of Multimedia Learning, 117-134. Cambridge University Press, 2005. https://www.cambridge.org/core/product/identifier/ CBO9780511816819A015/type/book_part.

GP, Harianto. Teologi PAK: Metode Dan Penerapan Pendidikan Kristen Dalam Alkitab. Yogyakarta: ANDI, 2017.

Hamad Ibnu; Komarudin; Mohandas Ramon; Sumadi Tjipto. Kurikulum 2013 : Tanya Jawab Dan Opini. Jakarta: Pusat Informasi dan Hubungan Masyarakat (PIH) Kementerian Pendidikan dan Kebudayaan, 2013.

Kasan, Tholib. Dasar-Dasar Pendidikan. Jakarta: Studia Press, 2009.

Koswara, D. Deni, and Halimah. Bagaimana Menjadi Guru Kreatif? Bandung: Pribumi Mekar, 2008.

Kuatandi, Cecep, and Bambang Sutjipto. Media Pembelajaran Manual Dan Digital. Edited by Risman Sikumbang. 2nd ed. Bogor: Ghalia Indonesia, 2013.

Lase, Delipiter, and Etty Destinawati Hulu. "Dimensi Spritualitas Dalam Kompetensi Kepribadian Guru Pendidikan Agama Kristen." SUNDERMANN: Jurnal Ilmiah Teologi, Pendidikan, Sains, Humaniora dan Kebudayaan 13, no. 1 (March 20, 2020): 13-25.

https://jurnal.sttsundermann.ac.id/index.php/sunder mann/article/view/24.

Mayer, Richard. E., and Roxana Moreno. "Animation as an Aid to Multimedia Learning." Educational
Psychology Review 14, no. 1 (2002): 87-99. https://link.springer.com/article/10.1023/A:101318 4611077.

Mayer, Richard E. Multimedia Learning. 3rd ed. New York: Cambridge University Press, 2020.

Miles, Matthew B., A. Michael Huberman, and Johnny Saldaña. Qualitative Data Analysis: A Methods Sourcebook. 3rd ed. New York, NY: SAGE Publications, Inc., 2014.

Moleong, Lexy J. Metodologi Penelitian Kualitatif. Bandung: Remaja Rosdakarya, 2017.

Naim, Ngainun. Menjadi Guru Inspiratif: Memberdayakan Dan Mengubah Jalan Hidup Siswa. Yogyakarta: Pustaka Pelajar, 2009.

Nasution, S. Teknologi Penddikan. Jakarta: Bumi Aksara, 2011. . Teknologi Pendidikan. Jakarta: Bumi Aksara, 2011.

Oktaria, Tri Ani, and Riswan Jaenudin. "Pengaruh Kreativitas Mengajar Guru Terhadap Hasil Belajar Siswa Pada Mata Pelajaran Ekonomi Di SMA N 1 Muara Padang Banyuasin Sumatera Selatan.” PROFIT 4, no. 2 (2017): 145-154. https://ejournal.unsri.ac.id/index.php/jp/article/vie w/5593.

Oktavia, Yanti. "Usaha Kepala Sekolah Dalam Meningkatkan Kreativitas Guru Dalam Pembelajaran Di Sekolah Dasar.” Jurnal Bahana Manajemen Pendidikan 2, no. 1 (2014): 808-831. http://ejournal.unp.ac.id/index.php/bahana/article/v iew/3828.

Pebrianto, Tinton Tri, and M Tauchid Noor. "Pengaruh Kreativitas Guru Mengajar Dan Minat Belajar Siswa Terhadap Hasil Prestasi Siswa Kelas XI Jurusan IPS Di SMAN Karubaga Kabupaten Tolikara.” Jurnal Penelitian dan Pendidikan IPS 9, no. 2 (2015): 1170-1180.

http://ejournal.unikama.ac.id/index.php/JPPI/articl e/download/1666/1345.

Prijanto, Jossapat Hendra. "Panggilan Sebagai Guru Kristen Wujud Amanat Agung Yesus Kristus Dalam Penanaman Nilai Alkitabiah Pada Era Digital [A Christian Teacher's Calling in Response to Jesus Christ's Great Commission in Instilling Biblical Values in a Digital Era]." Polyglot: Jurnal Ilmiah 13, no. 2 (August 2017): 13.

Rasam, Fadli, and Ani Interdiana Candra Sari. "Peran Kreativitas Guru Dalam Penggunaan Media Belajar Dan Minat Belajar Dalam Meningkatkan Prestasi Belajar Peserta Didik SMK Di Jakarta Selatan." Research and Development Journal of Education 5, no. 1 (2018): 97-113. https://journal.lppmunindra.ac.id/index.php/RDJE/ article/view/3391.

Russell, H Russell Bernard and Bernard H. Research Methods in Anthropology: Qualitative and Quantitative Approaches. Walnut Creek: AltaMira Press, 2006. 
Sardiman, A. M. Interaksi Dan Motivasi Belajar Mengajar. Jakarta: PT Raja Grafindo Persada, 2016.

Smit, Brigitte, and Anthony J. Onwuegbuzie.

"Observations in Qualitative Inquiry: When What You See Is Not What You See." International

Journal of Qualitative Methods 17, no. 1 (December 2018).

Sumiyantiningsih, Dien. Mengajar Dengan Kreatif \& Menarik. 3rd ed. Yogyakarta: ANDI, 2006.

Supriadi. Strategi Belajar Mengajar. Bandung: Alfabeta, 2011.

Tamara, Yesi, Angel Christie Pakasi, Desserly Krismawaty Wesly, and Edi Sujoko.

"Profesionalitas Yesus Sang Guru Agung Dalam Penggunaan Media Pembelajaran." Didache: Journal of Christian Education 1, no. 1 (June 2020): 65.

Utami, Munandar. Pengembangan Kreativitas Anak Berbakat. Jakarta: Rineka Cipta, 2016. 